\title{
The valens aqueduct of constantinople: hydrology and hydraulics
}

\section{Martin Crapper $^{1}$ (D)}

Received: 5 May 2020 / Accepted: 21 August 2020 / Published online: 8 October 2020

(c) The Author(s) 2020

\begin{abstract}
A hydrological and hydraulic engineering analysis has been carried out on the Valens aqueduct system constructed from around AD 345 and serving Constantinople. A GIS analysis of previous field observations combined with a digital elevation model confirmed the aqueduct's likely route and slope. Macrophysical Climate Modelling revealed that contemporary weather data was an appropriate proxy for the time of the aqueduct's construction, and modern flow data was obtained for some of the springs that fed the aqueduct. Existing, previously documented remains, especially at intakes, were considered, and the industry standard software HEC-RAS was used to simulate the performance of the aqueduct system with a view to understanding the amount of water it could have delivered to the city, the seasonal variation in supply and the most likely configuration of the aqueduct, where this was not clear from existing archaeology. It was concluded that the most likely configuration for the aqueduct system was a fourth and a fifth century channel continuing separately and in parallel to the city walls, which might have delivered flow the range of $0.73 \mathrm{~m}^{3} / \mathrm{s} \mathrm{in}$ the driest month of October to $1.73 \mathrm{~m}^{3} / \mathrm{s}$ in the wettest month of March over an average year.
\end{abstract}

Keywords Roman $\cdot$ Aqueduct $\cdot$ Constantinople $\cdot$ Hydrology $\cdot$ Hydraulics $\cdot$ Simulation

\section{Introduction and background}

The modern visitor to Istanbul sees a $971 \mathrm{~m}$ long aqueduct bridge commonly referred to as the Valens Aqueduct. In fact this bridge, impressive though it is, is just one small part of a water supply system stretching hundreds of kilometres into the Thracian forest, bringing water to the city that was the capital of the Roman Empire from AD 330. Contemporary sources attest to the lack of water, Themistius Oratio XIII noting the city "afficted with thirst and drought and not far from vanishing...". In response to what was apparently a seasonal problem, major aqueduct construction took place from around 340 to 373 (the fourth century line), with a further very significant extension around fifty years later (the

Martin Crapper

Martin.Crapper@northumbria.ac.uk

1 Department of Mechanical and Construction Engineering, Northumbria University, Newcastle upon Tyne NE1 8ST, UK 


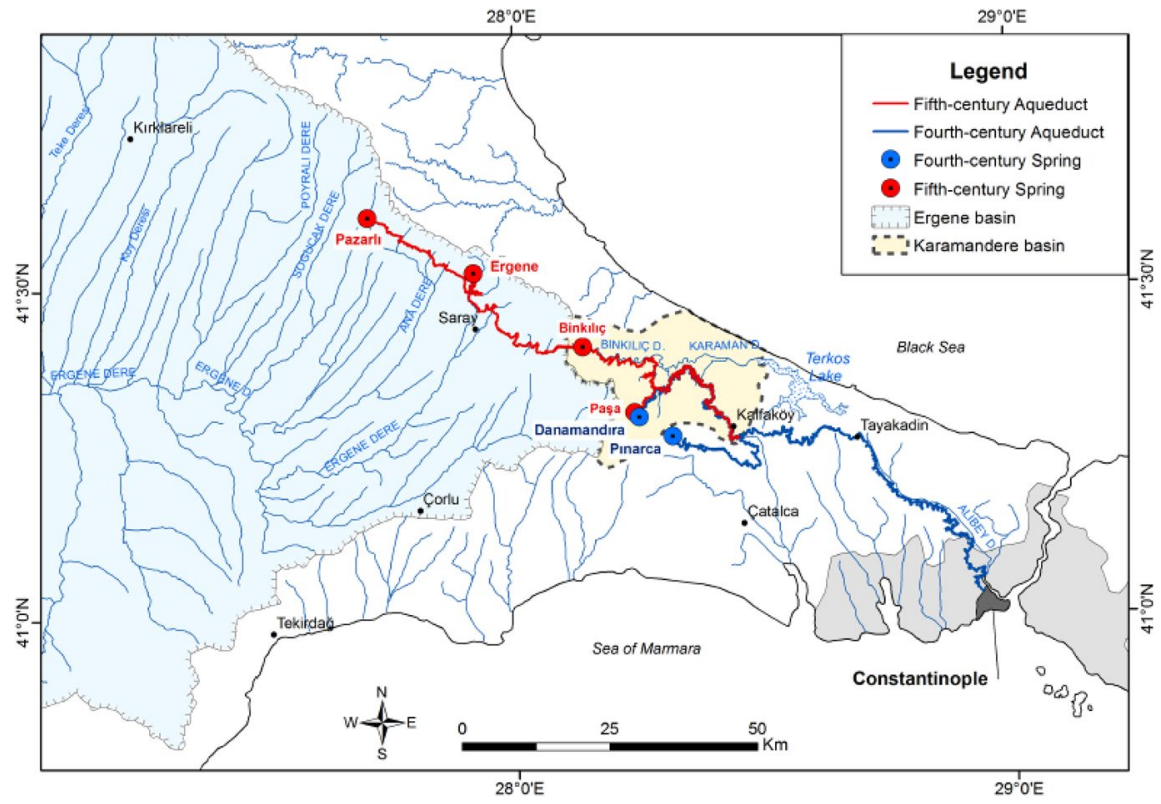

Fig. 1 Plan of the Valens aqueduct system showing fourth and fifth century lines and locations of main spring sources and catchments

fifth century line) (Crow et al. 2008a, b). Despite its length and importance, the system was very little considered by classical archaeologists until Çeçen (1996) and Crow et al. (2008a, b).

This latter study gave rise to a solid understanding of the arrangement of the system, which is shown in Fig. 1. The fourth century line has two main sources, at Danamandira (where the Kaynarca and Papu springs were adjacent) and at Pinarca, with the two branches merging into a single channel near Kalfaköy. This system was approximately $250 \mathrm{~km}$ long; the sources at Danamandira were $171 \mathrm{~m}$ above sea level (asl) with the walls of Constantinople being 65 masl. The fifth century extension took flow from springs at Pazarlı, 240 masl, via a branches at Ergene and Binkıliç and a long branch at Paşa, also near Danamandira. The fifth century system was therefore at least $180 \mathrm{~km}$ of additional aqueduct channel. This ran in parallel with the fourth century channel, at a lower elevation, in the central section, and may have either merged into the earlier line near Kalfaköy or continued as a completely separate channel to the city. There is insufficient archaeology in the region close to the city to determine which of these eventualities was the case, much of this area having been destroyed by more recent urban development of one of the world's megacities. The lengths of the channels easily justify Çeçen (1996)'s epithet of 'The Longest Roman Water Supply Line'. The channels were all of masonry, of a rectangular form with a vaulted cover, the walls up to the springing of the vault being lined with hydraulic mortar. Most channels were narrow, of width around $0.65 \mathrm{~m}$ and height to the top of the vertical wall (the vault springing) of around $1 \mathrm{~m} .{ }^{1}$ However the fifth century channel from

1 The total height to the apex of the vault was of course higher than this. 


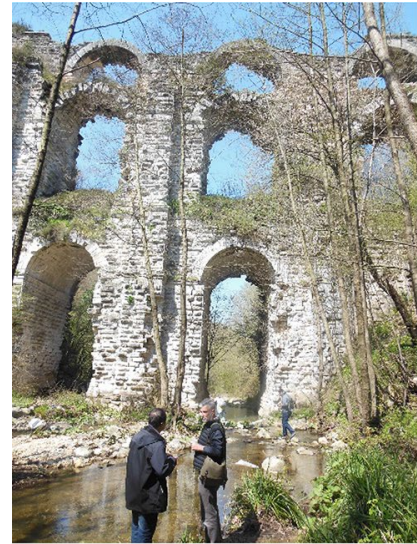

(a)

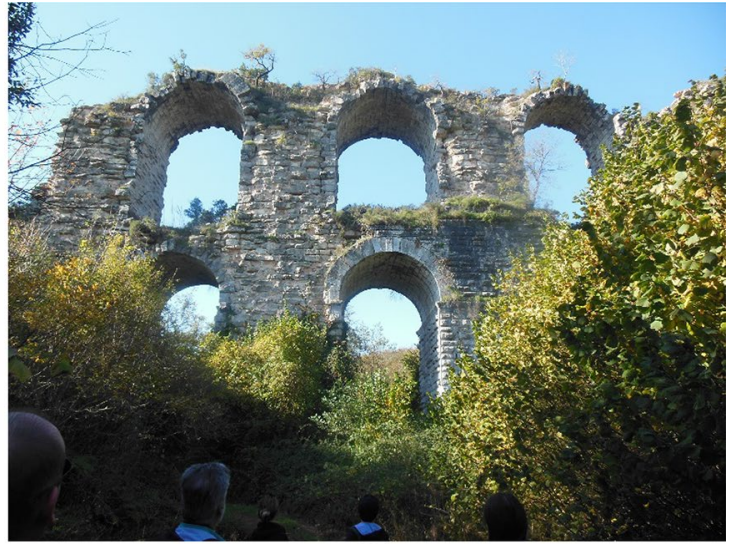

(b)

Fig. 2 Aqueduct bridges at a Kurşunlugerme and b Kumarlıdere

Safalaan to Kalfaköy was wide: $1.6 \mathrm{~m}$ in width and around $1.7 \mathrm{~m}$ high to the top of the vertical wall Crow et al. (2008a, b).

Outside Istanbul, the system is still little conserved and visited, much of it lying in relatively inaccessible areas; however there are remains of over 90 bridges and many sections of channel, including the spectacular multi-tiered bridges at Kurşunlugerme and Kumarlidere (Fig. 2). Whilst the archaeology is now quite well understood, there has not previously been any investigation into the function of the system as a piece of water engineering. The research presented here is intended to plug that gap.

\section{Aims}

The aims of this research were to investigate the hydrology and hydraulics of the Valens aqueduct system, and specifically to understand the hydraulic properties of the channels, such as their cross-section and slope, to study the amount of water available and capable of entering the aqueduct system, to examine the hydraulics of the aqueduct and so determine the amount of water that might have been delivered to the city of Constantinople, and to draw conclusions as to the likely configuration of the system where archaeology has not yet been able to clarify this.

\section{Hydraulic properties}

Fifty eight channel observations have been recorded for the entire system of fourth and fifth century lines. The fourth century channel was found to be a narrow conduit of width around $0.65 \mathrm{~m}$ from the springs to Kalfaköy, while the fifth century channel started as a narrow channel around $0.70 \mathrm{~m}$ wide, and widened to $1.60 \mathrm{~m}$ after Safalaan. In the section downstream of Kalfaköy, there are relatively few surviving channels, mostly around $0.85 \mathrm{~m}$ wide; however two of these, located south of Tayakadın, were reported to be $1.20 \mathrm{~m}$ and 


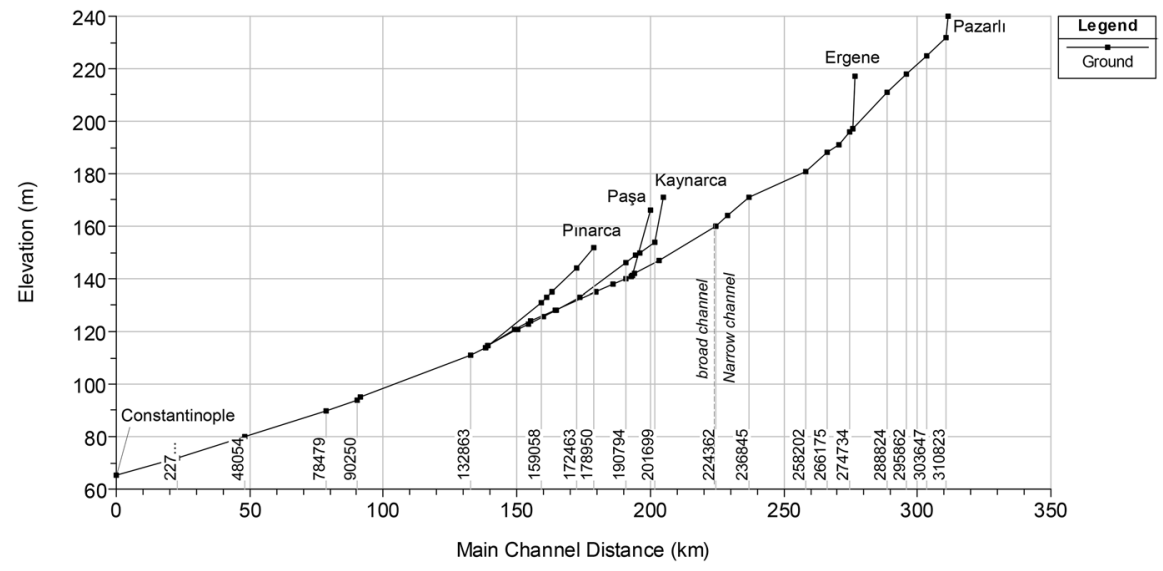

Fig. 3 The gradient profile of the Valens aqueduct system (Crapper et al. 2016)

$1.50 \mathrm{~m}$ wide (Crow et al. 2008a, b, 2009). In addition, field surveys gave GPS locations for 38 bridges and 27 channel sections (Maktav et al. 2009).

A digital elevation model of the aqueduct catchment was created, based on the Advanced Spaceborne Thermal Emission and Reflection Radiometer (ASTER) GDEM V2, released by NASA in 2011. This has a horizontal resolution of around $30 \mathrm{~m}$ and a vertical root mean squared error of $8.68 \mathrm{~m}$ against known GPS benchmarks. This model was imported into ArcGIS and combined with the GPS points of the aqueduct, with lengths in between the surveyed points being traced along contours at a constant slope. Adjustments were made to account for the known length of bridges spanning valleys, whilst the three tunnels on the system, where the channels pass under ridges, were assumed to have a steeper slope of $1 \mathrm{~m} / \mathrm{km}$ according to Hodge (2002, p. 271).

From this analysis, total lengths of the system are $245.9 \mathrm{~km}$ and $179.4 \mathrm{~km}$ for the fourth and fifth century lines respectively; the whole system would have been around $425 \mathrm{~km}$ long with the channels merging at Kalfaköy; a separate, parallel fifth century channel downstream of Kalfaköy would add a further $138 \mathrm{~km}$ of construction.

The GIS study also allowed calculation of the channel gradients. That of the fourth century line varies quite significantly, from around $0.7 \mathrm{~m} / \mathrm{km}$ from Kaynarca to Kalfaköy and $1.0 \mathrm{~m} / \mathrm{km}$ from Pinarca to Kalfaköy, to much flatter in the most downstream section after Kalfaköy, below $0.4 \mathrm{~m} / \mathrm{km}$. Steeper slopes are identified in the most upstream sections, close to the springs, with a maximum slope of $5.1 \mathrm{~m} / \mathrm{km}$. In the fifth century line, the gradient is also found to decrease as the channel continues downhill. In particular, the gradient of the most upstream section is on average $0.8 \mathrm{~m} / \mathrm{km}$, if neglecting the steeper stretch at the intake, while the following aqueduct section becomes much flatter, at $0.5 \mathrm{~m} / \mathrm{km}$. Similarly to the fourth century line, the conduits in the vicinity of the springs have a steeper gradient, around $4 \mathrm{~m} / \mathrm{km}$ at Pazarli.

A plot of the slope of the system is shown in Fig. 3, and the GIS study and channel geometry is fully detailed in Ruggeri (2018, Chapter 5 and Appendix A).

The final component of hydraulic properties is the friction factor. No further research was carried out in regard to this; in all the analyses carried out, Manning's equation was used, with a friction coefficient of 0.014 , corresponding to plaster-lined masonry, which was common for Roman aqueducts and observed by us in several of the surviving channels, 
for example at Pinarca and at Kumarlıdere. This value of Manning's ' $n$ ' follows the practice of Keenan-Jones et al. (2015), Motta et al. (2017) for Roman aqueducts.

\section{Water available for use}

Whilst there have been some studies on the possible water-carrying capacity of Roman aqueducts (for example Keenan-Jones et al. (2015); Motta et al. (2017) previously cited). A few, including Bobée et al. (2011) and Keenan-Jones (2013) have considered the amount of water available to flow into the aqueducts at various seasons, including some consideration of possible variations between ancient and modern times. Given the size and complexity of the Valens aqueduct catchment, the amount of water obtainable, or in modern terms, the hydrology of the catchment, must have been a serious consideration for its Roman designers.

The catchments of Karamandere and Ergene, in which the relevant springs are located is karst (Bono et al. 2001), i.e. a landscape formed by the dissolution of carbonate rocks, typically limestone. Such catchments are hydraulically complex, as each has a unique arrangement of fissures and cavities. The underground links between these often result in the hydrological catchment being bigger than the topographical catchment that would be defined from the ground slope at the surface, and there is no general model available to predict the runoff of such a catchment without individual site data relating rainfall to runoff and spring flow. In particular, the time response between rainfall and runoff can vary from very slow to very rapid. A full discussion of karst hydrology relating to the Valens aqueduct system is contained in Ruggeri (2018, Chapter 6).

Modern site data for the region is limited, and site data contemporary with the design and construction of the aqueduct is of course unavailable. Further, although karst changes slowly on average, sudden changes, due, for example to the collapse of a cave, are possible and there is no way of telling if such events have occurred since the aqueduct was commissioned.

\section{Hydrological data}

Two modern sources of hydrological data were available, a report from DSI, the Turkish government agency responsible for hydrology (DSI 1977) and a further range of data from the same institution, communicated privately. DSI (1977) focuses on the NE corner of the Ergene catchment, encompassing the springs that would have fed the fifth century extension of the aqueduct at Pazarlı and Ergene. As well as monthly average rainfall, it includes monthly average flow for the major springs, and yearly average for the minor ones, over the period 1969-1973. Combining GIS and geo-referencing with the information in DSI (1977), it is concluded that the spring reported as Pazarlı Ayazma may have been that providing the major source of water at the upstream end of the fifth century system. Another, much smaller spring, named Çakilli Ergenekorusu Kaynağ could have fed the aqueduct tributary there. 
The second source of data covers the period 1976-2016 (with not all years present in every record) with much more wide-ranging information from several weather stations and stream gauging stations, but it does not include spring flow data, and none of the stream gauging stations are particularly close to potential aqueduct springs, but are all further downstream.

\section{Historic climate}

Since all the hydrological data was relatively modern, it was important to consider whether the climate had changed significantly since the time of the Valens aqueduct's design. Macrophysical Climate Modelling (MCM) (Bryson et al. 2007) was employed to determine likely changes in monthly rainfall, maximum, minimum and mean temperatures between the period AD 350-750 when the Valens aqueduct was in use, and modern times. Eight weather stations were used, Kırkareli, Çorlu, Bahceköy, Alpullu, Florya, Kumköy, Yalova and Tekirdağ. Of these, only the first two at 232 and 173 masl were high enough for the rainfall recorded there to enter the aqueduct. Bahceköy is at 130 masl and the rest all below 40 masl. The results of the MCM process show some higher summer rainfall peaks in the 350-750 period, but the stations most relevant to the aqueduct, Kırkareli and Çorlu, show very little difference from modern rainfall and temperature pattens (Fig. 4). There is clearly no absolute way of validating these results, but it is concluded that modern weather data is a reasonable proxy for that that would have been observed at the time of the Valens aqueduct's construction and use.
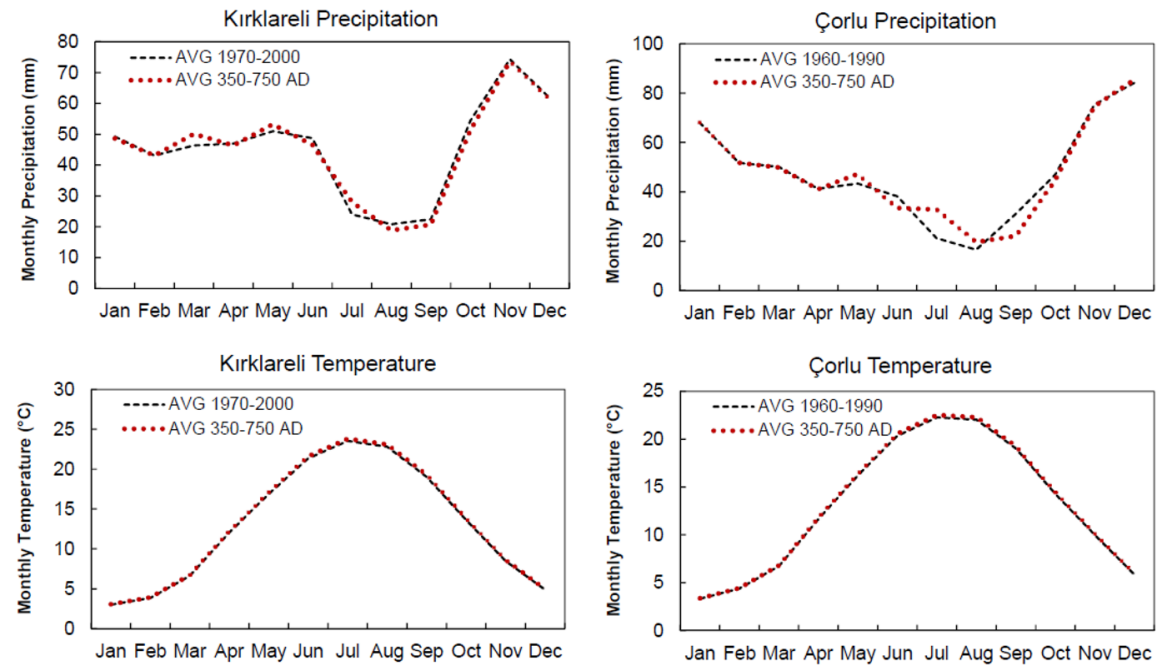

Fig. 4 Results of Macrophysical Climate Modelling (MCM) for Kırkareli and Çorlu weather stations showng difference in montly average temperature and rainfall between AD 350-750 and modern times (Ruggeri 2018) 


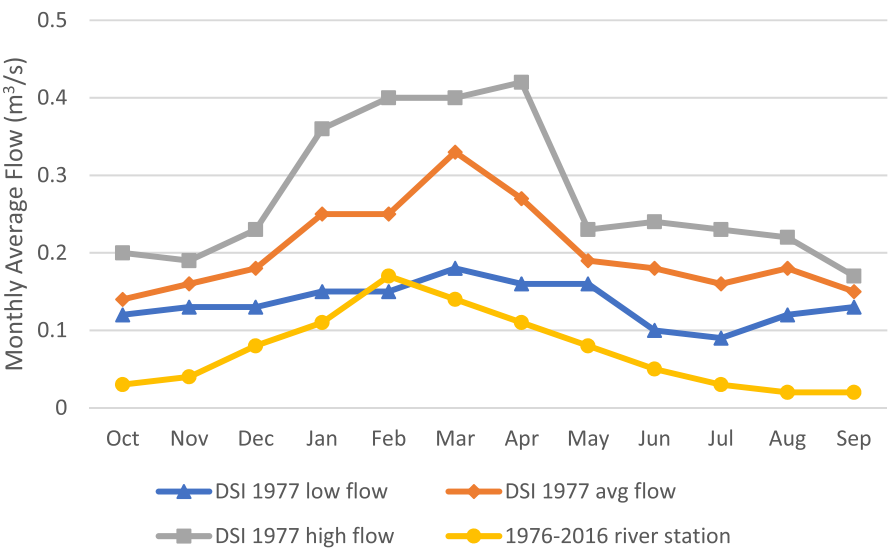

(a) Pazarlı Ayazma

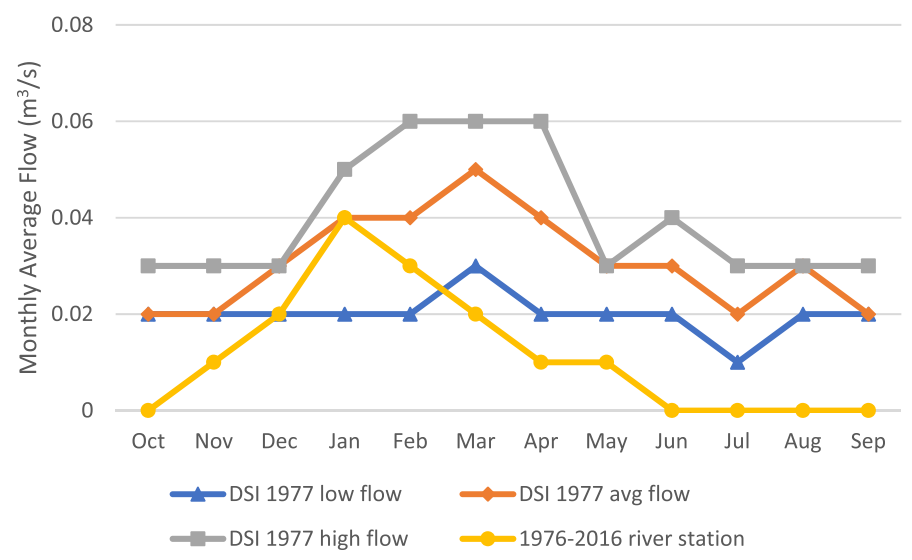

(b) Ergene

Fig. 5 Reconstructed hydrographs for springs for low, average and high flow scenarios and cross-check with river station data, a Pazarlı Ayazma and b Ergene

\section{Spring flow}

The monthly discharge records for the Pazarlı Ayazma spring from DSI (1977) were used to define a typical spring discharge hydrograph to assist in understanding the amount of water available to the Valens aqueduct system. Three annual hydrographs were produced, one from the minimum flow in each month, 1969-1973, one for the average flow in each month and one for the maximum flow for each month over those years of record. Results of this analysis for the spring flow are shown in Fig. 5. The spring flows at Ergene were similarly reconstructed for low, average and high flow scenarios. However, as this was a classified as a minor spring in DSI (1977), only annual average flows were available. It was therefore assumed that its montly variations were proprionately similar to those at the larger spring. Reconstructed flows for Ergene are also shown in Fig. 5. 


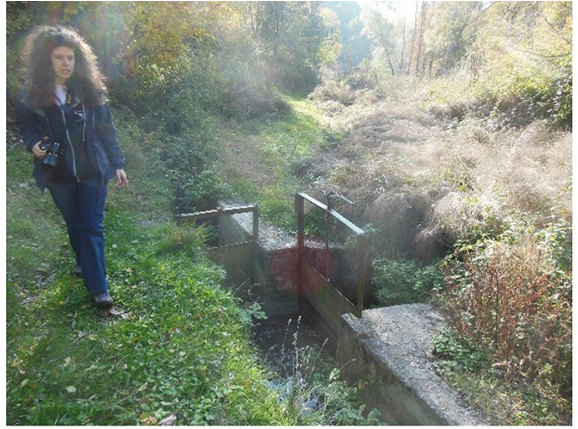

(a)

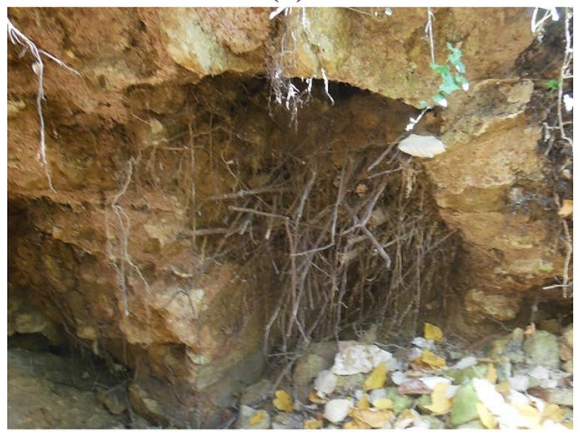

(c)

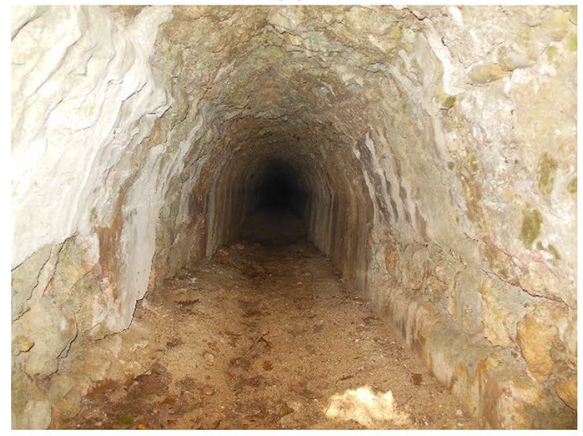

(e)

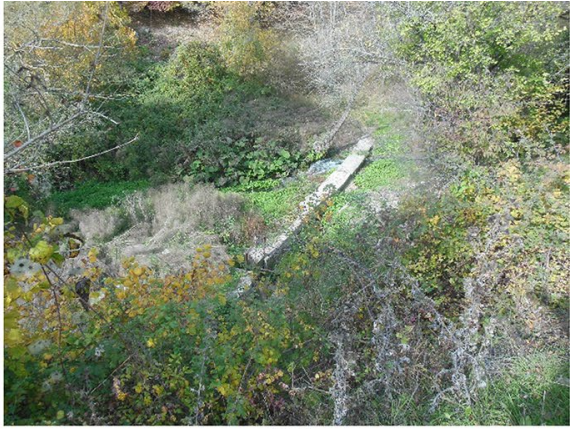

(b)

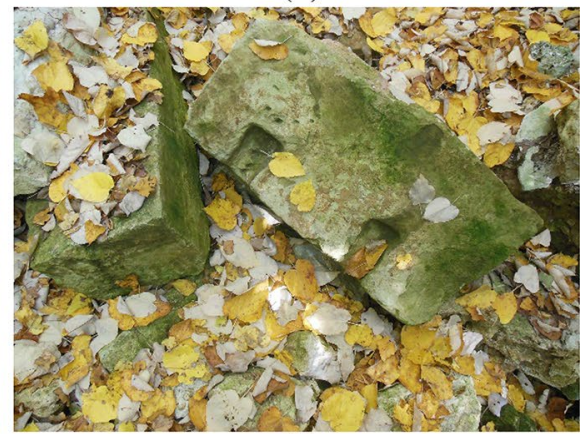

(d)

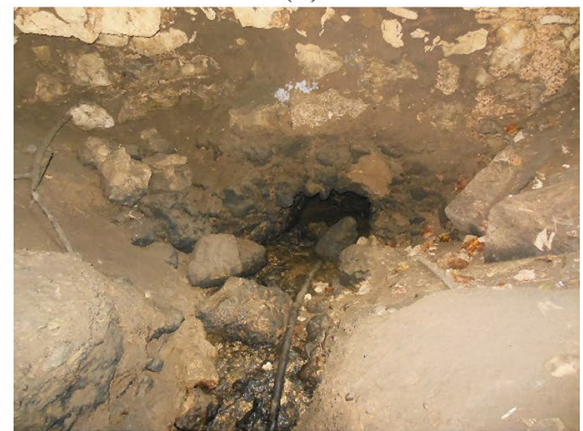

(f)

Fig. 6 Modern weir and sluice arrangement near intake at Pazarlı $(\mathbf{a}, \mathbf{b})$, the inlet to the aqueduct channel being hidden in the undergrowth behind Dr Ruggeri in (a); and springs at Pinarca showing aqueduct channel (c) and fallen masonry that may have been a weir of Roman construction (d) at the first spring; wellpreserved channel at the second spring (e); and channel (with a modern water pipe fed through it) at base of weir at the third spring (f)

As a sense-check on these data, more recent stream gauging stations were used. This data included stations D01A031, in the next valley from Pazarlı and D01A033 close to Ergene. Using a GIS analysis, a comparison was made between the topographical catchment upstream of these stations and that at the spring locations feeding the aqueduct, giving a possible proportionate relationship between the monthly flows measured at the stream gauging stations and those at the springs, these being the main feeders for all the rivers in the area. For Pazarl, the spring topographical catchment was 0.19 of that 
for river station D01A031 and for Ergene it was 0.02 that of D01A033. Applying this proportion to the measured river flows gave comparable results (Fig. 5). In each case the peak spring flow is in the January-April period and the monthly flows are of a similar order of magnitude.

\section{Intake arrangements}

The amount of water at the spring is an important consideration. However, there is no a priori reason to assume that all water emerging from a spring would enter the aqueduct system. The Roman designers may have been conscious of the need for spring water in the immediate locality of the spring; they would also have had to design and construct an intake structure.

Whilst it was not possible to undertake an archaeological investigation or take measurements of any kind, the intake arrangements at Pazarlı and Pinarca all survive to some extent and can be readily examined by any visitor. The author was thus able to visually inspect them from an engineering perspective. At Pazarli, the aqueduct has clearly been adapted for use in more recent times, up to the twentieth century, and the situation is a natural stream, fed by the spring, with a weir and sluice arrangement leading to the aqueduct channel (Figs. 6a, b). Here the aqueduct channel was identifiable in the undergrowth towards the back of Fig. 6 a.

At Pinarca, there are three springs with separate intakes. One is immediately outside a cave, where the aqueduct channel (Fig. 6c) leads off at the side of the natural stream emerging from the cave, and fallen masonry with clamp notches (Fig. 6d), in the stream bed suggests that a weir controlled the stream, diverting flow into the aqueduct, much like the altered system observed at Pazarlı. The second intake at Pinarca is a deep, welllike cave fed by a spring at its base, and feeding at least two aqueduct channels at different levels, the higher of which appears to be an overflow leading to the stream fed by the spring at the first intake (Fig. 6e). The third intake here is another cave with a weir-like wall constructed over the lower half of its entrance. At the base of this wall, in the centre, is the entrance to the aqueduct channel (Fig. 6f). Flows too high to enter the aqueduct would build up behind the weir, inside the cave, eventually overflowing into a natural stream.

All these surviving details suggest that the intake structure of choice for the aqueduct system may have been a weir intended to divert spring flow from its natural channel, but with some provision for continuation flow, at least in high flow situations. This makes sense, since a covered aqueduct channel would clearly have a maximum capacity, and failure to provide for overflow of excess spring water would possibly have had detrimental consequences.

Another feature of the intakes to the aqueduct system is their relative steepness. For example, between Pazarl1 and Safalaan, $76 \mathrm{~km}$ length of fifth century channel, the GIS analysis has shown an average slope of just below $1 \mathrm{~m} / \mathrm{km}$. However, closer to the intakes it is much steeper, $4 \mathrm{~m} / \mathrm{km}$ at Pazarlı and perhaps up to $20 \mathrm{~m} / \mathrm{km}$ at Ergene. This steepening near the intake appears to be the case for the other intakes across the whole aqueduct system Ruggeri et al. (2016) and may thus be considered a design feature. It may have been intended to speed water away from the intake quickly, since the steeper channel means that the absolute capacity of the intake region is greater than that of the channel immediately downstream, or it may have been a result of conservative surveying practices, ensuring the 
main aqueduct channel was below the spring elevation and using the most upstream section to complete the connection as necessary.

On balance it is concluded that the aqueduct intakes demonstrate evidence of deliberate design, and had an arrangement that would divert flow into the channel without a local constraint on the channel, but would provide for some overflow, at least at high flows.

\section{Remaining intakes_channel conveyance analysis}

In order to fully understand the aqueduct system, it is clearly necessary to have an idea of the water entering it at every intake, not just at the fifth century springs for which data was recoverable from DSI (1977). However none of the available data gave any real guidance as to quantities of water available at the remaining springs identifed by Crow et al. (2008a, b), i.e. at Binkıliç and Paşa on the fifth century line and at Danamandıra and Pinarca on the fourth century line.

To provide inflow information for subsequent modelling, flows at these locations were estimated by analyzing the proportion of total channel conveyance used at Pazarli and Ergene, where spring flow information was available, and assuming the remaining intakes were designed to give a similar utilization of total channel conveyance, i.e. assuming consistent design approach across all the intakes and channels.

The analysis was carried out by means of the industry standard river modelling package HEC-RAS (Brunner 2010). This applications software solves the well known St Venant Equations describing one-dimensional flow in open channels and provides many features to allow various hydraulic structures and situations to be simulated. It is appropriate for modelling Roman aqueduct channels which were designed to flow with a free surface (the vault at the top of the masonry channels being well above the water surface) and under gravity. Full details of the data used for the analysis and the complete results are included in Ruggeri (2018, Chapter 7 and Appendix D).

Steady-flow analyses were run for the the fifth century channel from Pazarlı to Safalaan, using the low, average and high flow scenarios previously defined (Fig. 5) and assuming the entire flow of the springs entered the aqueduct. Channel slope and length was from the GIS analysis, cross-section dimensions were taken from the observations of Crow et al. (2008a, b), and the frictional characteristics of the channels were kept constant with a Manning's n value of 0.014 as discussed earlier. Conveyance ratio was determined as the ratio of the cross-section shown to be taken up by the flow, divided by the total available cross-section of channel.

The critical section of the simulated section of channel, where conveyance ratios were highest, meaning the channel was most full, was between around 237 and $248 \mathrm{~km}$ from the city walls, upstream of the Safalaan tunnel. Here, for the high flow scenario, flow exceeded the maximum channel capacity. At the intakes, where the channel was steeper, the conveyance ratio was always lower, as expected. A typical performance for the section of channel was calculated by averaging the modelled conveyance ratio along the length of the channel, excluding the steeper intake sections. A further intake conveyance ratio was calculated for the Pazarlı intake only, corresponding to the most detailed hydrograph derived from the DSI (1977) report. These results are shown in Fig. 7.

The conveyance ratios in Fig. 7 were used as a basis to estimate flows at the remaining springs, imposing the conveyance ratio on the relevant channel section. The fourth century channels from Danamandira and Pinarca have been reasonably well documented, and are 


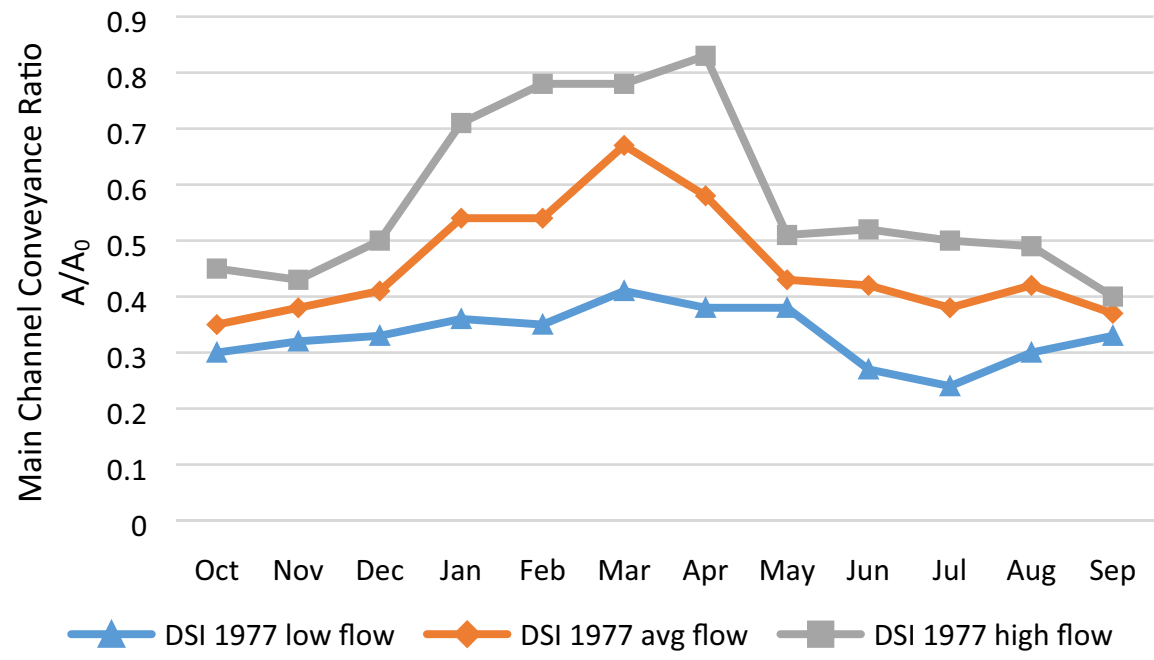

(a) main channel from Pazarlı to Safalaan

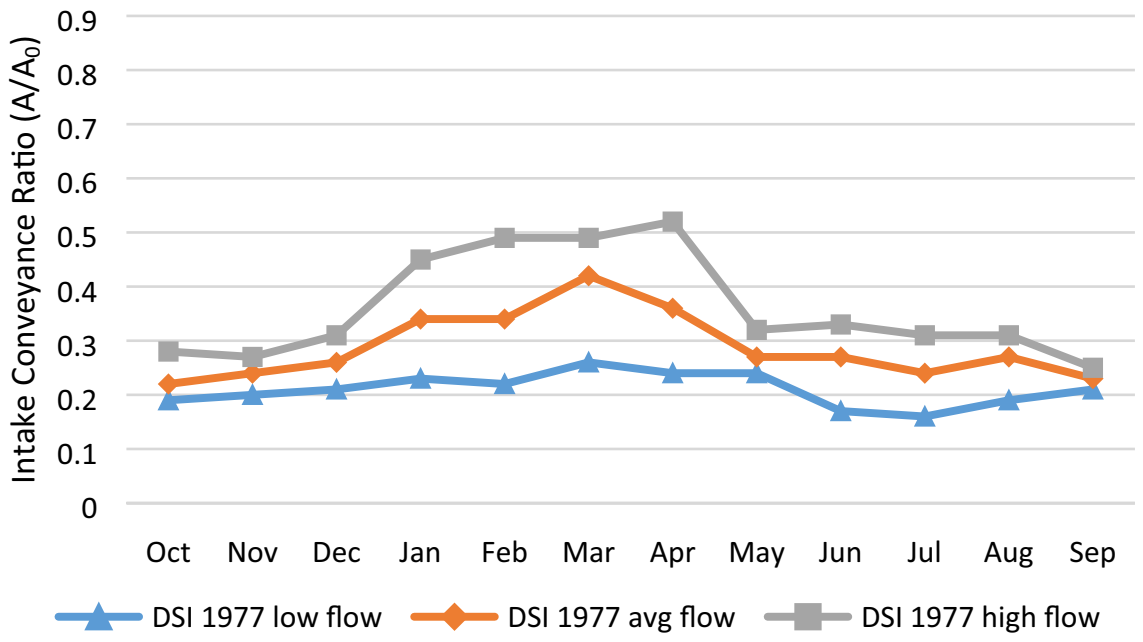

(b) Pazarlı intake channel

Fig. 7 Monthly conveyance ratio for typical and intake scenarios for fifth century channel where spring data is available from DSI report for a the main channel from Pazarlı to Safalaan and $\mathbf{b}$ the Pazarlı intake channel. $\mathrm{A}$ is the utilized cross-section of channel; $\mathrm{A}_{0}$ is the total cross-section available

of comparable size with the Pazarlı to Safalaan section of the fifth century line; therefore the typical convenance ratios were used here, in effect assuming that all these channels would behave similarly along much of their length. At Binkıliç and Paşa, there is no record of archaeology, so no conclusion can be made about the behaviour of a long length of channel. It was therefore surmised that these springs would feed via an intake designed 
0.5

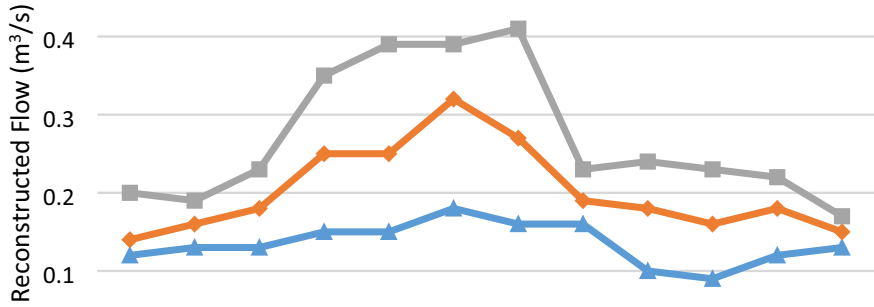

0

Oct Nov Dec Jan Feb Mar Apr May Jun Jul Aug Sep

$\longrightarrow$ DSI 1977 low flow DSI 1977 avg flow $\longrightarrow$ DSI 1977 high flow

(a) Danamandira

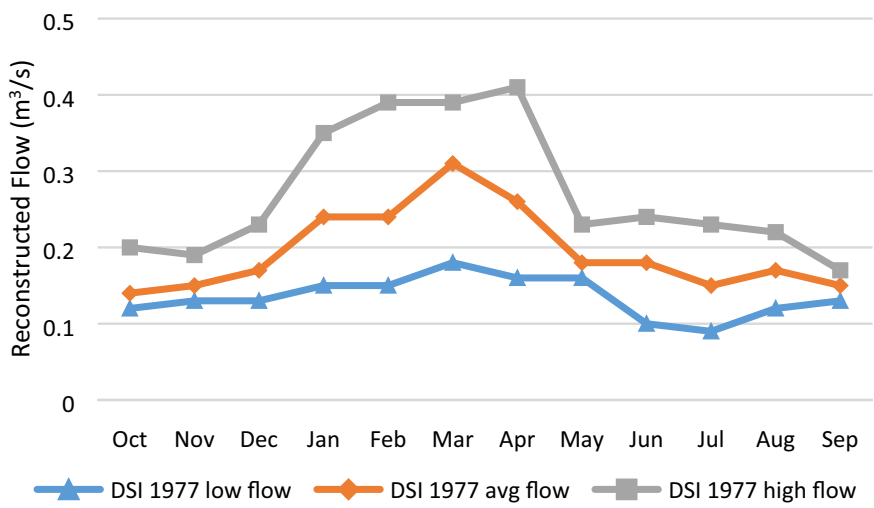

(b) Pinarca

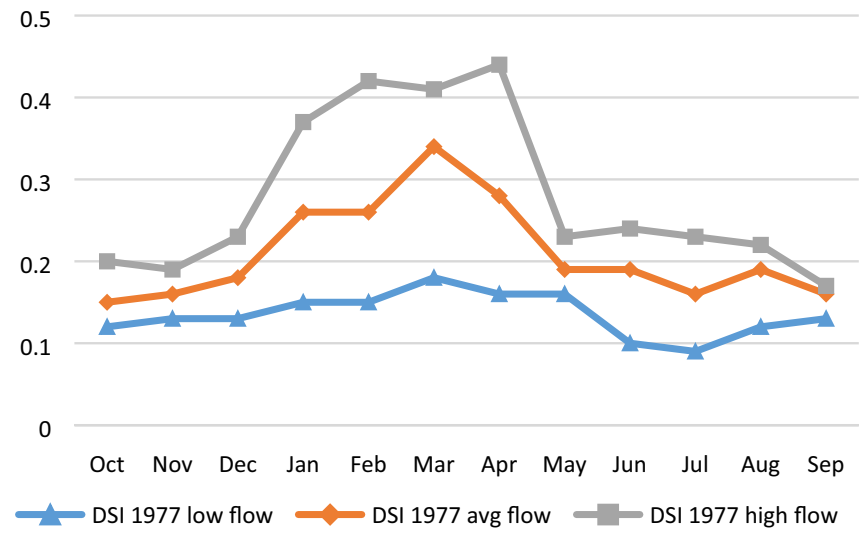

(c) Paşa and Binkıliç

Fig. 8 Reconstructed inflow rates for a Danamandıra, b Pinarca and c Paşa and Binkıliç springs, obtained by imposing similar channel conveyance ratios to the Pazarlı - Safalaan and Ergene channels 
Table 1 Maximum capacity of intakes determined from HEC-RAS steady flow analysis

\begin{tabular}{llllll}
\hline Spring & Pazarlı & Ergene & Danamandıra & Pinarca & Paşa/Binkılıç \\
\hline Maximum capacity of intake $\left(\mathrm{m}^{3} / \mathrm{s}\right)$ & 0.55 & 0.15 & 0.55 & 0.40 & 0.55 \\
\hline
\end{tabular}

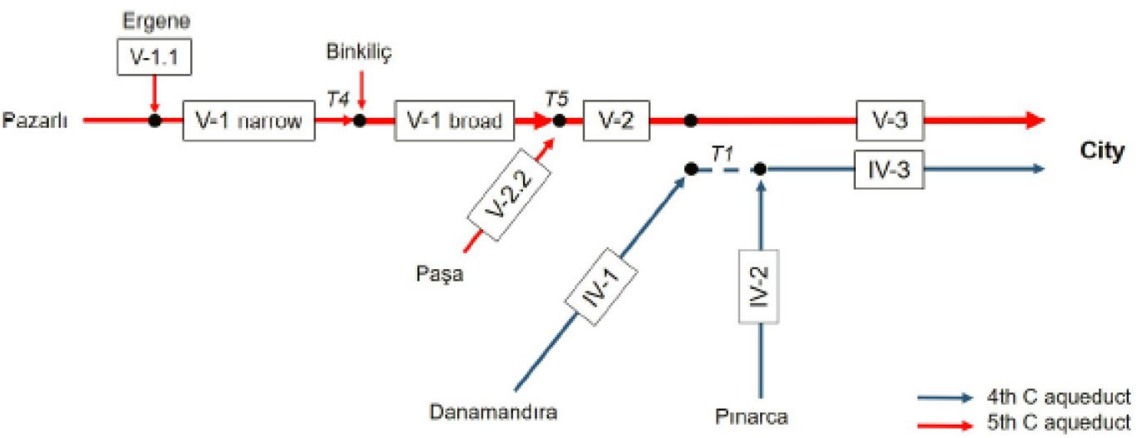

(a)

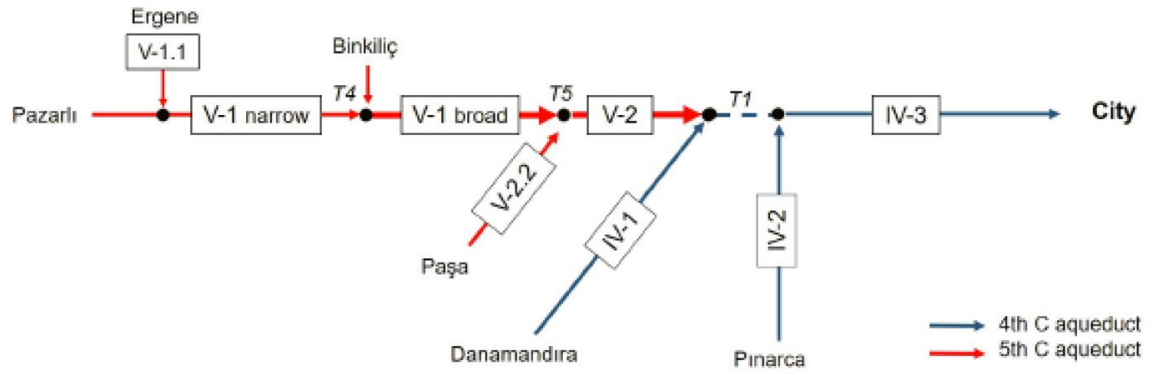

(b)

Fig. 9 Schematics of the Valens aqueduct simulations; a fourth and fifth century lines as separate systems; b merged system. The reaches are numbered using IV for the fourth century channels and V for the fifth century (Ruggeri 2018)

with a similar objective to the Pazarlı intake, and the conveyance ratio for that intake channel was therefore taken as the design ratio.

The inflow estimation was carried out by repeated HEC-RAS steady flow simulation, varying the inflow until the required conveyance ratio was obtained. The resulting conveyance ratios are shown in Fig. 8.

Further steady flow HEC-RAS analyses were carried out to determine the maximum capacity of the intakes at each location. In every case, the limiting factor was not the steeper intake channel itself, but the restriction where the channel slope reduced somewhat downstream. The intake maximum capacities are shown in Table 1, and in each case it is apparent that the monthly average flow determined is always well below the intake capacity.

The range of assumptions made in coming to these figures will be apparent to the reader; clearly in coming to a view regarding flows that took place over 1600 years ago, assumptions are always going to be necessary. According to MCM, the climate of modern 


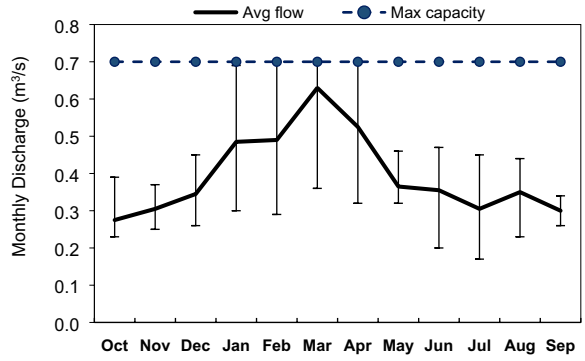

(a)

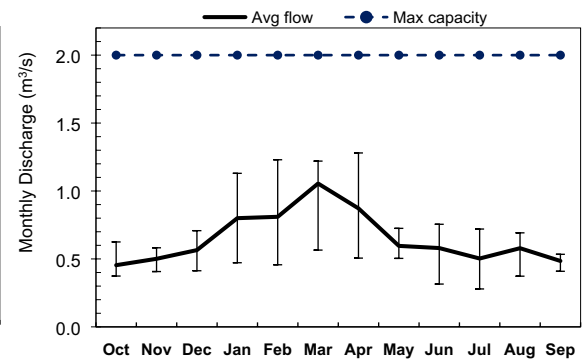

(b)

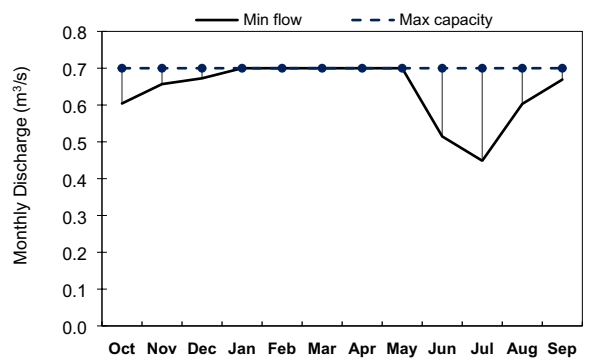

(c)

Fig. 10 Simulated monthly average flow reaching the city walls for a fourth century system, average flow scenario; $\mathbf{b}$ fifth century system if it continued separately to the city walls, average flow scenario; and $\mathbf{c}$ merged system, low flow scenario. In each case the maximum capacity of the aqueduct system is shown (Ruggeri 2018)

times is considered to be a reasonable proxy for that at the time the Valens aqueduct system was constructed; the DSI (1977) data for the at springs of Pazarlı Ayazma and Çakilli Ergenekorusu Kaynağ Pazarlı and Ergene, and the readily observable remains of intakes at Pazarlı and Pinarca indicate a reasonably consistent approach to design, justifying the imposition of similar conveyance ratios as an appropriate method of estimating inflows in the absence of more detailed information.

\section{Hydraulic analysis}

Reconstructed inflows for the springs were used as the basis for HEC-RAS simulations of the aqueduct system with the aim of examining aqueduct performance, capacity, and effects such as attenuation of peak flows. The aim of this part of the study was to assess the amount of water delivered to the city and its seasonal variation. Three different possible configurations were examined, these being the fourth century line alone, as envisaged at its original commissioning, the fifth century line imagined as a completely separate system, with a channel parallel, but not connected to the fourth century line from Kalfaköy to the city, and the merged system, assuming that the fifth century construction was an extension to the original, joining with it at Kalfaköy. The systems modelled are illustrated in Fig. 9. 
Table 2 Estimates of per capita flow delivered by the Valens aqueduct for different system configurations, populations and flow scenarios

\begin{tabular}{|c|c|c|c|c|c|c|c|c|}
\hline \multirow[b]{2}{*}{$\begin{array}{l}\text { System } \\
\text { configura- } \\
\text { tion }\end{array}$} & \multirow[b]{2}{*}{$\begin{array}{l}\text { Period } \\
\text { (AD) }\end{array}$} & \multirow[b]{2}{*}{ Population } & \multicolumn{3}{|c|}{$\begin{array}{l}\text { Average flow over year for dif- } \\
\text { ferent scenarios }\left(\mathrm{m}^{3} / \mathrm{s}\right)\end{array}$} & \multicolumn{3}{|c|}{$\begin{array}{l}\text { Flow per capita per day for dif- } \\
\text { ferent scenarios (L) }\end{array}$} \\
\hline & & & Low flow & $\begin{array}{l}\text { Average } \\
\text { flow }\end{array}$ & High flow & Low flow & $\begin{array}{l}\text { Average } \\
\text { flow }\end{array}$ & High flow \\
\hline $\begin{array}{l}\text { Fourth } \\
\text { century } \\
\text { line }\end{array}$ & $425-450$ & 188,000 & 0.27 & 0.39 & 0.51 & 124 & 179 & 234 \\
\hline $\begin{array}{l}\text { Fifth } \\
\text { century } \\
\text { line }\end{array}$ & & & 0.69 & 1.04 & 1.36 & 317 & 478 & 625 \\
\hline $\begin{array}{l}\text { Merged } \\
\text { system }\end{array}$ & & & 0.64 & 0.70 & 0.70 & 294 & 322 & 322 \\
\hline $\begin{array}{l}\text { Fifth } \\
\text { century } \\
\text { line }\end{array}$ & $527-565$ & 375,000 & 0.69 & 1.04 & 1.36 & 159 & 240 & 313 \\
\hline $\begin{array}{l}\text { Merged } \\
\text { system }\end{array}$ & & & 0.64 & 0.70 & 0.70 & 147 & 161 & 161 \\
\hline
\end{tabular}

Modelled reaches were given numbers commencing with IV for fourth century and V for fifth century, as indicated in the figure.

Channel geometry was based on the GIS analysis, with the dimensions of the narrow and wide channels broadly as discussed earlier, modified to precise values where available from field observation and with additional cross-sections interpolated by HEC-RAS every $250 \mathrm{~m}$ as recommended to give stable computations. Flow simulations were carried out in the mixed regime to allow for sub- to supercritical flow transition and vice-versa. Full details of the geometry used in the computations are given in Ruggeri (2018, Appendix D).

For steady flow simulations, the upstream boundary condition at the intakes was set to critical flow, on the basis of the steep nature of the intake channels; for unsteady flow a flow hydrograph provided the upstream boundary conditions. In either case, the downstream boundary condition, representing the point at which the aqueduct system crossed the Theodosian Walls into the city of Constantinople, was set to normal depth, there being no information on which to base an alternative assumption. For unsteady flow modelling, a sensitivity analysis was carried out to determine the effects of computational timestep, and for an hourly flow hydrograph a timestep of $5 \mathrm{~min}$ was found to give acceptable results.

\section{Seasonal variation of flow}

Steady flow simulations were carried out using the monthly average low, average and high flow scenarios described above; where the aqueduct capacity was exceeded, the flow was capped. In practice this would represent an overflow scenario. No archaeological evidence has been found to indicate the presence of any overflow structures but it would have been perfectly possible for them to be provided. 
Table 3 Travel time for flow derived from steady flow simulations for different reaches of the aqueduct system

\begin{tabular}{|c|c|c|c|}
\hline \multicolumn{4}{|l|}{ Fourth century system } \\
\hline Aqueduct section & Reach & $\begin{array}{l}\text { Length } \\
(\mathrm{m})\end{array}$ & $\begin{array}{l}\text { Travel time } \\
(\mathrm{h}, \mathrm{min})\end{array}$ \\
\hline Danamandıra to Kalfaköy East & IV-1 & 66,817 & 26 h 50 m-36 h 58 m \\
\hline Pınarca to Kalfaköy East & IV-2 & 40,787 & 14 h 31 m-19 h 59 m \\
\hline Kalfaköy East to Constantinople & IV-3 & 138,473 & 60 h $17 \mathrm{~m}-81$ h $35 \mathrm{~m}$ \\
\hline Total for fourth century system & & & (days, h) \\
\hline Danamandıra to Constantinople & IV-1; IV-3 & 205,290 & $3 d 14 h-4 d 22$ h \\
\hline Pinarca to Constantinople & IV-2; IV-3 & 179,260 & $3 \mathrm{~d} 02 \mathrm{~h}-4 \mathrm{~d} 05 \mathrm{~h}$ \\
\hline \multicolumn{4}{|l|}{ Fifth century system } \\
\hline Pazarlı to Ergene bridge & V-1 narrow & 35,766 & 11 h $29 \mathrm{~m}-17 \mathrm{~h} 00 \mathrm{~m}$ \\
\hline Ergene to Binkılıç & V-1 narrow & 46,785 & 17 h 42 m-25 h 19 m \\
\hline Binkılıç to Ballıgerme South & V-1 broad & 35,640 & $11 \mathrm{~h} 11 \mathrm{~m}-18 \mathrm{~h} 20 \mathrm{~m}$ \\
\hline Balligerme South to Kalfaköy West & $\mathrm{V}-2$ & 54,171 & 16 h 54 m-26 h 25 m \\
\hline Kalfaköy West to Constantinople & $\mathrm{V}-3$ & 138,991 & 48 h 48 m-75 h 19 m \\
\hline \multicolumn{4}{|l|}{ Tributary channel } \\
\hline Ergene source to Ergene Bridge & $\mathrm{V}-1.1$ & 940 & $1 \mathrm{~h} 23 \mathrm{~m}-2 \mathrm{~h} 06 \mathrm{~m}$ \\
\hline Pas, a source to Balligerme South & $\mathrm{V}-2.2$ & 6981 & 0 h $14 \mathrm{~m}-0$ h $20 \mathrm{~m}$ \\
\hline Total for fifth century system & & & (days, h) \\
\hline Pazarlı to Ballıgerme South & $\mathrm{V}-1$ & 118,191 & $1 d 17 \mathrm{~h}-2 \mathrm{~d} 12 \mathrm{~h}$ \\
\hline Pazarlı to Kalfaköy West & $\mathrm{V}-1 ; \mathrm{V}-2$ & 172,362 & $2 \mathrm{~d} 10 \mathrm{~h}-3 \mathrm{~d} 14 \mathrm{~h}$ \\
\hline Pazarlı to Constantinople & $\mathrm{V}-1 ; \mathrm{V}-2 ; \mathrm{V}-3$ & 311,353 & $4 d 10 h-6 d 19 h$ \\
\hline
\end{tabular}

The reach numbers are as in Fig. 9

Considering the fourth century system alone, the maximum capacity of reach IV-3 of $0.7 \mathrm{~m}^{3} / \mathrm{s}$ (Fig. 9) is reached from February to April for the high flow scenario. In the average flow scenario, the system discharge at the city walls was modelled as $0.28 \mathrm{~m}^{3} / \mathrm{s}$ in the driest month of October and $0.63 \mathrm{~m}^{3} / \mathrm{s}$ in the wettest month of March.

Cross-sectional average flow velocities ranged from 0.5 to $0.8 \mathrm{~m} / \mathrm{s}$ in the main channel, increasing up to $1.5 \mathrm{~m} / \mathrm{s}$ closer to the intakes where the channel is steeper. This velocity is sufficient to ensure self-cleansing from sediment without undue risk of damage due to scour. Froude numbers are everywhere less than unity, indicating subcritical flow throughout, without the difficulties sometimes associated with flow transitions. Overall the fourth century aqueduct seems to be well designed.

For the fifth century line imagined as continuing all the way to the city walls without merging with the fourth century line, the discharge reaching the city walls was simulated as varying from 0.45 to $1.1 \mathrm{~m}^{3} / \mathrm{s}$ in the average flow scenario. Velocities were in the range $1.2-1.4 \mathrm{~m} / \mathrm{s}$, and supercritical flow was shown only in the Ergene tributary. Here the modelled gradient is steep, but this representation was based on limited information in this area, there being no detailed field observations to feed into the GIS analysis. Model results clearly indicate that, if the inflow estimates above are reasonable, the $1.6 \mathrm{~m}$ wide channel in the fifth century system was never mobilized to capacity; at most it was 30-40\% full. This does bring its ambitiously-sized design into question. 

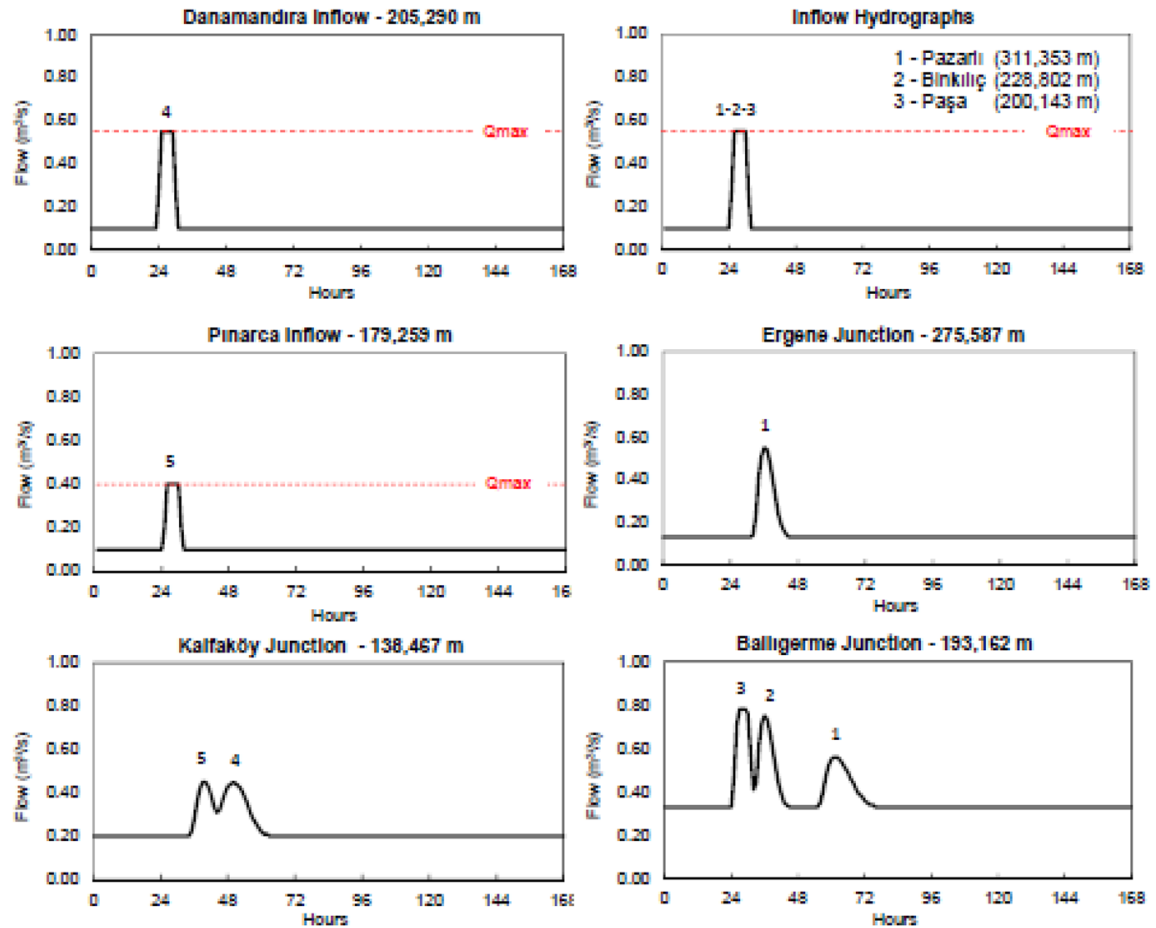

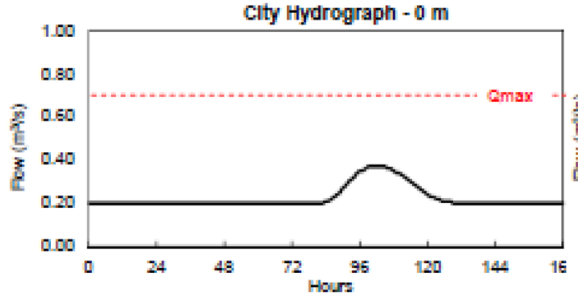

(a)

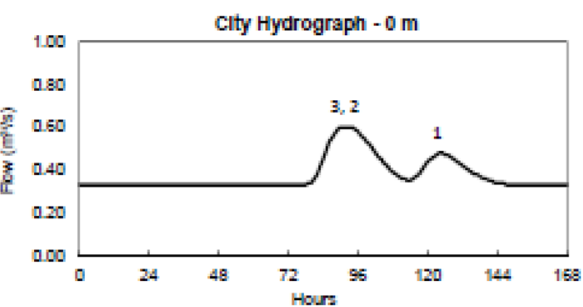

(b)

Fig. 11 Attenuation of single-peak hydrograph, shown at significant locations (intakes and junctions) from upstream to downstream: a fourth century system; b fifth century system. Qmax indicates the (local) maximum channel capacity where this is not off the scale of the graph (Ruggeri 2018)

The merged system, Fig. 9b, understandably shows a more significant restriction on aqueduct performance. The already well-utilized IV-3 branch at the downstream end of the fourth century line is now required also to carry the flow from the fifth century line, merging with it at Kalfaköy. This results in significant potential overflow throughout this section, with the aqueduct full for most of the year even at the low flow scenario, and the water being delivered to the city walls being limited to the reach IV-3 capacity of $0.7 \mathrm{~m}$ for most of the year.

Plots of the month-by-month flow at the city walls are shown in Fig. 10. In Fig. 10a, b, the lines represent the average flow scenario with the error bars showing the low and high flow scenarios. In Fig. 10c, for the merged system, only the low flow scenario is plotted as the others use the whole capacity of the aqueduct all year. In the former two simulations, the seasonal variation of flow is apparent. 
As mentioned, archaeological investigation has not so far confirmed the arrangement of channels downstream of Kalfaköy after construction of the fifth century line. Separate systems would have delivered much more water (the total being that of Fig. 10a, b combined) but with seasonal variation; a merged system would deliver less water but with significant overflow losses and more constantly over the year.

The population of Constantinople at the time of the Valens aqueduct system's use has been the subject of some speculation. Jacoby (1961) produced estimates of around 188,000 in the reign of Theodosius II, from AD 402 to 450 , rising to 375,000 by the time of Justinian (AD 527-565). Using these as a basis of estimating the per capita use per day, and averaging the month-by-month figures in Fig. 10 over the year gives the per capita use for all purposes (including industrial use) as shown in Table 2. The lower figure corresponds to the higher, Justinian-age population. As a reference, a modern design figure for domestic water use is around $200 \mathrm{~L} / \mathrm{capita} / \mathrm{day}$. It should be noted that there was also another aqueduct supplying Constantinople, dating from the Hadrianic period, and there were also some wells and rainwater harvesting arrangements providing more local supplies, so the figures in the table are not the only water available to the population. Even the lower figures are not unreasonable, though in the drier months there would have been a degree of water stress.

\section{Unsteady flow}

It is worth considering the possible effects of unsteady flow such as might arise from the rapid response of the springs feeding the aqueduct system to storm events. The maximum and minimum travel time of flow down each leg of the aqueduct was first calculated based on steady flow simulations for the low and high flow scenarios, and is presented in Table 3. The longest travel time for the fourth century system from Danamandira to Constantinople is almost 5 days, and that for the fifth century system from Pazarlı to Constantinople was almost 7 days, suggesting that considerable attenuation of storm peaks might be possible over these distances. However, the differing travel times for the various reaches suggest that whether or not storm peaks entering the system at the various springs would have coincided further down would be a consequence of many different variables.

In order to explore this further, hypothetical six hour-duration storms were simulated using the unsteady flow capabilities of HEC-RAS. The storm hydrographs were simply six-hour blocks of flow corresponding to the previously calculated maximum intake capacity at each spring location, on top of a base flow of $0.1 \mathrm{~m}^{3} / \mathrm{s}$. They were introduced simultaneously at the beginning of the situation for each of the five main springs, in this case ordered from upstream to downstream as (1) Pazarlı; (2) Binkıliç; and (3) Paşa on the fifth century line, and (4) Danamandira; and (5) Pinarca on the fourth century line. Results for the fourth and fifth century system assuming a separate channel all the way to the city are shown in Fig. 11.

As can be seen, there is some coalescing and attenuation of peaks, though of course had the storm hydrographs commenced at a different start time in the different locations - which is more likely than not in practice - the pattern of coalescence would be different. All are however contained within the various aqueduct channels and would have had minimal effect on the water supply to the city. 


\section{Discussion on system configuration}

The significant unanswered question is that of the configuration of the Valens aqueduct system downstream of Kalfaköy. Did the fifth century channel continue separately and in parallel to its earlier sister, or did it merge? Related to this question is why the fifth century channel from Safalaan to (at least) Kalfaköy was so large, given that the inflows identified do not appear to utilize anything like its full capacity. There is insufficient archaeology to answer these questions, but engineering analysis may add some insight.

To design a large channel to merge into a narrow channel, as would be the case were the merged system the true arrangement, seems to be poor design, particularly when this leads to overflows of hard-sought and expensively transported water. The only advantage for this is the evening out of water delivery to the city over the year. However, from around $\mathrm{AD} 421$, immediately following the completion of the fifth century aqueduct channel, the city was engaged in constructing cisterns, some of them very large, to store water. These may have been intended for contingencies such as sieges, but even so the investment seems incongruous with the discarding of water from an over-capacity downstream channel in a merged aqueduct system. Another interpretation is that, in the case of separate systems, the seasonal variation shown in Fig. 10a, b became more apparent and measures taken to store water in the wetter parts of the year. Only archaeology will address these questions; in the meantime, based on these engineering design considerations, the author is of the view that the separate, parallel systems is the most likely configuration.

There are many reasons for the upstream channel being wider; for example there may have been, or it may have been hoped there would be additional springs along the route to increase the water supply, though this makes no sense for the case of the merged system. There may also have been some understanding that the wide channel may have had a storage function, perhaps with appropriate controls along its length: perhaps as much as $200,000 \mathrm{~m}^{3}$ of water could have been stored along this length with appropriate engineering. Of course it is also possible that the builder may have been able to make more money from building a larger channel, as has been suggested in the context of the Aqua Anio Novus at Rome Motta et al. (2017).

\section{Conclusions and recommendations}

A wide ranging hydrological and hydraulic engineering study has been carried out into the Valens aqueduct system serving Constantinople. This aqueduct system is a remarkable achievement of ancient water engineering that is little studied and, outside the centre of modern Istanbul, not being actively conserved and not easily visited.

It was concluded that:

- On the basis of Macrophysical Climate Modelling analysis, modern data is a reasonable proxy for climate contemporary with the aqueduct's construction.

- Modern data for the springs of Pazarlı Ayazma and Çakilli Ergenekorusu Kaynağ is likely to be a good representation of the springs feeding the fifth century channel at Pazarlı and Ergene, and shows a clear seasonal variation with the peak flow being in March and the driest period in October. 
- The readily observable remains of intakes at Pazarlı and Pinarca indicate a reasonably consistent approach to design, justifying the imposition of similar conveyance ratios as an appropriate method of estimating inflows at other springs serving different parts of the aqueduct.

- The water delivered to the city depends on the aqueduct configuration in the downstream section, where the fifth century channel may have continued as a separate, parallel line all the way to the city, or may have merged with the fourth century channel around Kalfaköy.

- The flow delivered by the fourth century channel to the city walls ranged from 0.28 $\mathrm{m}^{3} / \mathrm{s}$ in the driest month of October and $0.63 \mathrm{~m}^{3} / \mathrm{s}$ in the wettest month of March for an average flow scenario at the springs; for the fifth century line, the flow ranged from 0.45 to $1.1 \mathrm{~m}^{3} / \mathrm{s}$, giving a total range for the two lines continuing in parallel to the city of between 0.73 and $1.73 \mathrm{~m}^{3} / \mathrm{s}$. If the systems merged, the flow delivered to the city was limited by the capacity of the most downstream channel section, this being $0.7 \mathrm{~m}^{3} / \mathrm{s}$, over most of the year.

- In almost all cases, flow in the aqueduct was subcritical with no difficult flow transitions, and the flow velocities were in the range $0.5-1.5 \mathrm{~m} / \mathrm{s}$, indicating good design for self-cleansing from sediment without undue risk of scour.

- Estimating the population for Constantinople suggests the aqueduct may have delivered in the range of 124-625 L/capita/day for all uses, averaged over the year; an equivalent modern standard being $200 \mathrm{~L} / \mathrm{capita} /$ day. Drier months might have given rise to some water stress; and

- Given that the seasonal variation of flows is apparent in the analysis, that the merged system gave rise to considerable overflows in most flow scenarios, and that shortly after the completion of the fifth century channel, the city embarked upon major investment in large storage facilities, all of which are incongruous with good engineering design, it seems most likely that the fifth century system continued as a separate system all the way to the city; however there is insufficient archaeology to confirm this, or otherwise.

In the light of this, the following recommendations are made:

- Further archaeology should be carried out. In particular, there are at least four tunnels on the route of the aqueduct system through Thrace, and remains of these must survive and be identifiable by suitable techniques. Exploration should also be carried out in the area closer to the city in an attempt to confirm or otherwise the existence of separate or merged fourth and fifth century channels.

- Better modern spring flow data for springs close to the aqueduct intake should be sought, for example from modern water facilities or bottling plants, and the hydrological analysis revisited in this light.

- A speleological investigation of the karst at in the region of the aqueduct sources should be carried out if possible to determine in more detail the age, nature and stability of the karst; and

- The aqueduct remains outside Istanbul should be conserved and protected, and made more available to the visitor. This should be done with appropriate interpretation and with sensitivity to the local environment, communities and economy in the region.

Acknowledgements This work was funded by the Leverhulme Trust under grant agreement RPG-2013410, for which gratitude is expressed. The project team comprised Professor Martin Crapper (Northumbria 
University), Professor James Crow, Dr Simon Smith, Dr Riley Snyder (University of Edinburgh), Dr Francesca Ruggeri (WSP) and Dr Kate Ward (University of Dundee). The contribution of Dr Ruggeri in particular to the GIS analysis and HEC-RAS processing in this paper is gratefully acknowledged. Dr Ruggeri has pursued a career in civil engineering consultancy and did not wish to be involved as an author of this paper. Ercan Beşik of DSI (General Directorate of State Hydraulic Works), Erzurum, Turkey and Dr Sevinç Sirdaş of the Faculty of Aeronautics and Astronautics, Meteorological Engineering Department, Istanbul Technical University are thanked for their contribution to obtaining hydrological data for Thrace, and Dr Bülent Arıkan, of the Eurasia Institute of Earth Sciences, also at Istanbul Technical University is thanked for his assistance with the Macrophysical Climate Modelling analysis.

Funding This work was funded by the Leverhulme Trust under Grant agreement RPG-2013-410.

Data availability The GIS data used in this research is available via the Edinburgh Research Archive at https ://dx.doi.org/10.7488/ds/2433

Code availability The code used in this research was HEC-RAS from the US Army Corps of Engineers, and is freely available at https://www.hec.usace.army.mil/software/hec-ras/

\section{Compliance with ethical standards}

Conflict of interest The author declares that he has no conflicts of interest.

Open Access This article is licensed under a Creative Commons Attribution 4.0 International License, which permits use, sharing, adaptation, distribution and reproduction in any medium or format, as long as you give appropriate credit to the original author(s) and the source, provide a link to the Creative Commons licence, and indicate if changes were made. The images or other third party material in this article are included in the article's Creative Commons licence, unless indicated otherwise in a credit line to the material. If material is not included in the article's Creative Commons licence and your intended use is not permitted by statutory regulation or exceeds the permitted use, you will need to obtain permission directly from the copyright holder. To view a copy of this licence, visit http://creativecommons.org/licenses/by/4.0/.

\section{References}

Bobée C et al (2011) High-resolution (PIXE) analyses of carbonate deposits in a Roman aqueduct (Fréjus, SE France): implications for the study of palaeohydrological variability and water resources management in southern Gaul during the Roman period. Archaeometry 53:241-260

Bono P et al (2001) The water supply of Constantinople: archaeology and hydrogeology of an Early Medieval city. Environ Geol 40(11-12):1325-1333

Brunner GW (2010) HEC-RAS, River analysis system - user's manual (version 4.1), U.S. Army Corps of Engineers (USACE).

Bryson RA et al (2007) An introduction to the archaeoclimatology macrophysical climate model. In: Bryson RA, DeWall KM (eds) A paleoclimatology workbook high resolution site specific acrophysical climate modeling. Hot springs, the mammoth site, South Dakota, pp 3-11

Çeçen K (1996) The longest roman water supply line. İstanbul, Türkiye Sınai Kalkınma Bankası

Crapper $\mathrm{M}$ et al (2016) A steady flow hydraulic model of the 4th and 5th century aqueducts supplying constantinople 4th iwa international symposium on water and wastewater technologies in ancient civilizations. Coimbra, Portugal

Crow J et al (2008a) The water supply of Byzantine Constantinople. Society for the promotion of roman studies, London

Crow J et al (2008b) Survey in thrace 2007-2008. Anatolian Archaeol 14:15-16

Crow J et al (2009) Survey in thrace august-september 2008. Bulletin Brit Byz Stud 37:51-55

DSI, G. D. o. S. H. W. G. a. G. D. (1977). Ergene Kuzeyi: Hidrojeolojik Etut Raporu / North of the Ergene: Hydrogeological Investigation.

Hodge T (2002) Roman Aqueducts and Water Supply. Bristol Classical Press, London

Jacoby D (1961) La population de Constantinople à l'époque Byzantine: un problème de démographie urbaine. Byzantion 31:81-110 
Keenan-Jones D (2013) Large-scale water management projects in Roman Central-Southern Italy. The Ancient Mediterranean Environment between Science and History. Columbia University Press, W V Harris New York, pp 233-256

Keenan-Jones D et al (2015) Travertine-based estimates of the amount of water supplied by ancient Rome's Anio Novus aqueduct. J Archaeol Sci Rep 3:1-10

Maktav D et al (2009) Integration of remote sensing and GIS for archaeological investigations. Int J Remote Sens 30(7):1663-1673

Motta D et al (2017) Hydraulic evaluation of the design and operation of ancient rome's anio novus aqueduct. Archaeometry 59(6):1150-1174

Ruggeri F (2018) Engineering the Byzantine Water Supply of Constantinople: mapping, hydrology and hydraulics of the long aqueducts outside the City. The University of Edinburgh, Edinburg

Ruggeri F et al (2016) A GIS-based assessment of the Byzantine water supply system of Constantinople 4th IWA International Symposium on Water and Wastewater Technologies in Ancient Civilizations. Coimbra, Portugal

Publisher's Note Springer Nature remains neutral with regard to jurisdictional claims in published maps and institutional affiliations. 